p-ISSN: $2338-4794$

e-ISSN: 2579-7476

Vol.9. No. 1 Januari-April 2021

\title{
PENGARUH DISIPLIN DAN LINGKUNGAN KERJA TERHADAP KINERJA KARYAWAN PT. SARANA RESWARA ABADI
}

\author{
Sri Puji Astuti 1) \\ 1) Mahasiswa Program Studi Manajemen FE UNKRIS \\ Wiwik Rachmarwi ${ }^{2)}$ \\ 2) Dosen Program Studi Manajemen FE UNKRIS \\ Alamat: Kampus UNKRIS, Jatiwaringin Jakarta Timur \\ Email : rachmarwi@gmail.com
}

\begin{abstract}
To analyze the effect of discipline and work environment on employee performance PT. Sarana Reswara Abadi. This research is a causal associative research with a quantitative approach. This research is a causal associative research with a quantitative approach. The population and sample of this research are employees of PT. Reswara Abadi ingredients are taken based on the Slovin formula with a random sampling technique. Data collection using a questionnaire that has been tested for validity and reliability. The data analysis technique was performed using partially and simultaneous regression analysis. The Result discipline and work environment have a positive and significant effect on the performance of the employees of PT. Sarana Reswara Abadi, either partially and simultaneous.
\end{abstract}

Keywords: Discipline, work environment and employee performance

\section{PENDAHULUAN}

Dalam kehidupan sehari-hari dan juga dalam suatu perusahaan, dibutuhkan peraturan-peraturan yang dapat mengatur dan membatasi setiap kegiatan dan perilaku individu didalamnya. Namun peraturan-peraturan tersebut tidak ada artinya apabila individu tersebut tidak mau menjalankan dan tidak disertai pula dengan sanksi bagi pelanggarnya.

Penyesuaian diri pada tiap-tiap individu terhadap sesuatu yang mengatur dirinya, akan menciptakan suasana atau lingkungan yang tertib dan nyaman. Begitu pula didalam suatu perusahaan, akan sangat penting bagi karyawan dalam menjalankan dan mentaati aturan-aturan yang sudah ditetapkan perusahaan, agar terciptanya ketertiban dan kenyamanan dalam lingkungan berkinerja. Dengan kata lain, disiplin pada karyawan sangat dibutuhkan, karena dapat berpengaruh terhadap tujuan perusahaan dan akan sulit dicapai apabila tidak adanya disiplin, begitu pula pada lingkungan kerja yang nyaman dan tertib tentu didalamnya ada disiplin yang dijalankan dengan taat.

Seharusnya karyawan memahami dengan dimilikinya disiplin yang baik, maka akan tercapai pula keuntungan yang berguna baik bagi perusahaan maupun bagi karyawan itu sendiri. Oleh karena itu, diperlukan kesadaran pada tiap karyawan dalam mematuhi peraturan-peraturan yang berlaku. Begitu pula perusahaan itu sendiri berupaya agar peraturan yang dibuat bersifat mudah dipahami dan adil, yaitu aturan berlaku baik bagi pimpinan tertinggi maupun bagi karyawan yang terendah.

Memasuki era globalisasi saat ini, sangat diperlukan sekali sumber daya manusia yang tentunya bermutu karena maju mundurnya perusahaan sangat bergantung pada kualitas karyawannya, 
semakin baik kualitas karyawan didalam suatu perusahaan maka semakin tinggi pula daya saing perusahaan terhadap perusahaan lain atau kompetitor. Sumber daya manusia pada suatu perusahaan perlu dikelola dengan baik dan profesional agar terwujud keseimbangan antara kebutuhan karyawan dengan tuntutannya dan kemampuan perusahaan. Sumber daya manusia merupakan modal utama untuk menunjukkan keberhasilan dan upaya meningkatkan dayaguna dan pencapaian tujuan suatu perusahaan, karena majunya suatu perusahaan tidak terlepas dari peranan manusia sebagai penggerak perusahaan. Hal ini dikarenakan manusia mempunyai kemampuan untuk mengelola dan menjalankan perusahaan sehingga tujuan perusahaan dapat tercapai dengan baik, karena kenyataannya dilapangan harus berhadapan dengan orang-orang yang memiliki latar belakang yang berbeda, oleh karena itu perlu adanya sosok pemimpin yang tepat yang dapat meningkatkan kinerja sumber daya manusia dalam perusahaan. Untuk meningkatkan kinerja sumber daya manusia dalam manajemen yang efektif dibutuhkan adanya karyawan yang berkompeten dibidangnya. Kinerja karyawan ini dapat dipengaruhi oleh beberapa hal yang diantaranya adalah disiplin dan lingkungan kerja, yang apabila keduanya berjalan dengan baik maka kinerja yang dihasilkan akan sesuai dengan yang di inginkan perusahaan.

Karyawan merupakan aset yang berharga bagi perusahaan dan memiliki peran yang sangat strategis yaitu sebagai pemikir, perencana, dan pengendali segala aktivitas perusahaan. Setiap perusahaan selalu berharap agar para karyawannya mempunyai prestasi, karena dengan memiliki karyawan yang berprestasi maka akan memberikan keuntungan yang optimal bagi perusahaan. Masalah perusahaan yang sering dihadapi yaitu terkait dengan masalah sumber daya manusia, dimana hal tersebut menjadi tantangan tersendiri bagi manajemen dalam mengelolanya. Dalam melaksanakan pekerjaan, karyawan dan perusahaan merupakan dua hal yang saling membutuhkan, karena apabila karyawan berhasil mencapai tujuan dan dapat memberikan kemajuan bagi perusahaan maka keuntungan diperoleh bagi kedua belah pihak. Bagi seorang karyawan, keberhasilan merupakan suatu bentuk aktualisasi dari potensi diri dan peluang untuk memenuhi kebutuhan hidup. Namun bagi PT. Sarana Reswara Abadi yang bergerak dibidang Manage Service adalah sebagai sarana dalam menuju pertumbuhan dan perkembangan dimasa yang akan datang.

Sesuai dengan kondisi tersebut, perusahaan harus dapat mampu menyesuaikan dengan adanya perubahanperubahan, yang dengan perubahan tersebut baik secara langsung maupun tidak langsung akan mempengaruhi kinerja karyawan dan akan berpengaruh pula pada kondisi perusahaan. Pengaruh disiplin terhadap kinerja karyawan sangatlah penting, begitu juga pengaruh lingkungan kerja terhadap kinerja karyawan yang pula penting bagi suatu perusahaan.

Kondisi di perusahaan tersebut adalah tidak tercapainya achivement (target pemasangan), yang berdampak pada tidak tercapainya tujuan perusahaan dalam mengelola karyawan untuk berkinerja. Dalam hal disiplin, masih adanya karyawan yang belum mengerti dan menjalankan fungsi disiplin, hal ini terbukti dengan adanya karyawan yang tidak mengikuti aturan yang berlaku, dengan ketidakhadirannya dalam masuk kerja. Berikut ini adalah tabel dan grafik data juga frekuensi kehadiran karyawan Manage Service ( EDC Bank Mandiri ): 
Tabel 1: Data Kehadiran Karyawan EDC Mandiri

Periode Oktober - Desember 2019

\begin{tabular}{ccccc}
\hline No. & Bulan & $\begin{array}{c}\text { Karyawan } \\
\text { Hadir }\end{array}$ & $\begin{array}{c}\text { Karyawan } \\
\text { Tidak Hadir }\end{array}$ & $\begin{array}{c}\text { Total } \\
\text { Karyawan }\end{array}$ \\
\hline 1. & Oktober & 213 & 19 & 232 \\
2. & November & 218 & 14 & 232 \\
3. & Desember & 208 & 24 & 232 \\
\hline & Rata-rata Kehadiran & $\mathbf{2 1 3}$ & $\mathbf{1 9}$ & $\mathbf{2 3 2}$ \\
\hline & \% Kehadiran & $\mathbf{9 1 . 8 \%}$ & $\mathbf{8 . 2 \%}$ & $\mathbf{1 0 0 \%}$ \\
\hline
\end{tabular}

Dalam hal berkinerja, terdapat beberapa hari yang sulit untuk tercapainya achivement (target pemasangan), hal ini dikarenakan beberapa hal pula yang diantaranya: adanya karyawan yang tidak masuk kerja namun tidak memberi kabar dengan ketidakhadirannya pada atasan, kurangnya rasa kesadaran para karyawan tentang pentingnya mereka dalam menentukan tercapainya target pemasangan (instalasi). Seharusnya para karyawan menyadari bahwa kinerja tinggi mereka sangat diharapkan, karena semakin banyak karyawan yang memiliki kinerja tinggi, maka produktivitas dan profitabilitas perusahaan secara keseluruhan dapat meningkat sehingga perusahaan akan dapat bertahan dalam persaingan global.

Menurut Sedarmayanti (2013), mengungkapkan bahwa: "Kinerja merupakan terjemahan dari performance yang berarti hasil kerja seorang pekerja, sebuah proses manajemen atau suatu organisasi secara keseluruhan, dimana hasil kerja tersebut harus dapat ditunjukkan buktinya secara nyata dan dapat diukur (dibandingkan dengan standar yang telah ditentukan)".

Disiplin menjadi awal pembuka dan mendasar pada hal target pemasangan yaitu sebagai target perusahaan pada umumnya. Kurangnya kesadaran bagi para karyawan tentang betapa pentingnya mereka dalam hal tercapainya pemasangan, dengan ketidakhadiran mereka sebagai ujung tombak pemasangan, maka akan sulit karyawan dalam mencapai target pemasangan.
Apabila mereka tidak dapat masuk kerja, seharusnya karyawan tersebut memberi kabar pada atasan mereka beberapa jam sebelum masuk kerja agar dapat digantikan dengan karyawan lain, walau hal ini menambah cost (upah lembur) bagi karyawan yang menggantikan dalam mengisi tugasnya yang tidak dapat masuk kerja, namun ini adalah upaya dalam memenuhi target pemasangan. Lalu pada jam yang seharusnya karyawan sudah jalan untuk melakukan pemasangan mereka memperlambat jam keberangkatan karena tidak adanya atasan yang melihat, dengan perilaku tersebut menimbulkan adanya lost time (waktu yang terbuang) akibat lamanya jam operasional yang tidak sesuai sehingga menimbulkan target pemasangan tidak tercapai. Disiplin merupakan sikap sadar atau kesediaan seorang karyawan untuk melakukan dan mentaati aturan-aturan yang ditetapkan oleh perusahaan. Karyawan dengan disiplin yang baik diharapkan dapat mampu menyelesaikan tugasnya dengan efektif dan efisien serta tepat pada waktunya.

Dalam hal ini, disiplin seorang karyawan bukan hanya sekedar dilihat dari absensi semata, melainkan ada pula penilaian dari sikap karyawan tersebut dalam menjalankan tugasnya. Karyawan yang memiliki disiplin tinggi tidak akan menunda pekerjaanya dan selalu berusaha menyelesaikan tepat pada waktu yang ditentukan meski tidak ada pengawasan langsung dari atasan. (Setiawan, 2013).

Begitupun dalam hal lingkungan kerja. Lingkungan (kondisi jalan) yang 
panas , hujan, berdebu dan macet akan mempengaruhi performa dalam berkinerja dan menjadi kendala dalam mencapai target pemasangan. Dalam hal ini pada tanggal 10 Oktober 2017 di TEMPO.CO, Jakarta. Ketua Pengurus Pusat Perhimpunan Dokter Spesialis Jiwa Dr. Eka Viora SpKJ, menyebutkan bahwa lingkungan kerja yang buruk tak hanya memicu resiko kesehatan fisik, tapi juga kesehatan jiwa. Adapun beberapa hal yang di akibatkan lingkungan kerja yang buruk, diantaranya : kesehatan fisik (hipertensi, diabetes, dan gangguan pola makan), kesehatan jiwa (kecemasan, depresi, gangguan panik, dan penggunaan zat berbahaya/alkohol), perilaku agresif (mudah marah dan tersinggung). "Lingkungan kerja yang tidak sehat ini pada akhirnya akan berdampak pada ketidakhadiran atau absenteeism, rendahnya motivasi dan kinerja serta hilangnya produktivitas," katanya.

Seorang karyawan yang bekerja di lingkungan kerja yang mendukungnya untuk bekerja secara optimal akan menghasilkan kinerja yang baik, begitupun sebaliknya jika seorang karyawan bekerja dalam lingkungan kerja yang kurang baik dan tidak mendukung untuk berkinerja secara optimal maka akan membuat karyawan tersebut menjadi malas, cepat lelah, sehingga kinerjanya pun akan rendah. Maka dari itu perusahaan diharapkan dapat menyediakan lingkungan kerja yang memadai seperti : lingkungan fisik (lingkungan bersih, pertukaran udara yang baik, ruangan panas dan bising yang dalam batas normal), serta lingkungan non fisik (suasana kerja karyawan, hubungan antar sesama karyawan, hubungan antara karyawan dengan atasan). Lingkungan kerja yang baik dapat mendukung pelaksanaan kerja, dengan kata lain karyawan yang memiliki semangat bekerja akan meningkatkan kinerjanya. (Sidanty, 2015).
Tujuan penelitian ini adalah untuk mengetahui pengaruh disiplin dan lingkungan kerja terhadap kinerja karyawan PT. Sarana Reswara Abadi.

\section{LANDASAN TEORI}

\section{Disiplin}

Disiplin merupakan faktor utama yang diperlukan sebagai alat penilaian terhadap karyawan yang tidak ingin merubah sifat dan perilakunya. Sehingga seorang karyawan dikatakan memiliki kinerja yang baik jika karyawan tersebut memiliki rasa tanggung jawab terhadap tugas yang diberikan kepadanya. Bagi perusahaan dengan adanya disiplin yang baik akan menjamin terlaksananya aturan yang dibuat, membantu kelancaran dalam berkinerja sehingga mendapatkan hasil yang optimal. Bagi karyawan akan menghasilkan suasana yang menyenangkan sehingga akan menambah semangat dalam bekerja.

Davis terjemahan Dharma (2012) mengungkapkan bahwa: "tindakan manajemen untuk memberikan semangat kepada pelaksanaan standar organisasi merupakan suatu pelatihan yang mengarah pada upaya membenarkan dan melibatkan pengetahuan, sikap dan perilaku karyawan sehingga ada kemauan pada diri karyawan untuk menuju pada kerja dan prestasi yang lebih baik lagi". Selanjutnya Menurut Sutrisno (2016) disiplin adalah "perilaku seseorang yang sesuai dengan peraturan, prosedur kerja yang ada atau disiplin adalah sikap, tingkah laku, dan perbuatan yang sesuai dengan peraturan dari organisasi baik tertulis maupun tidak tertulis".

Disiplin yang baik adalah disiplin diri. Kecenderungan orang normal adalah melakukan apa yang menjadi kewajibannya dan menepati aturan permainan. Organisasi atau perusahaan yang baik harus berupaya menciptakan peraturan atau tata tertib yang akan 
menjadi rambu-rambu yang harus dipenuhi oleh seluruh karyawan dalam organisasi. Menurut Singodimedjo dalam Sutrisno (2016) peraturan-peraturan yang akan berkaitan dengan disiplin antara lain: 1). Peraturan jam masuk, pulang, dan jam istirahat. 2). Peraturan dasar tentang berpakaian, dan bertingkah laku dalam pekerjaan. 3). Peraturan cara-cara melakukan pekerjaan dan berhubungan dengan unit kerja lain. 4). Peraturan tentang apa yang boleh dan apa yang tidak boleh dilakukan oleh para karyawan selama dalam organisasi dan sebagainya.

Sanksi pelanggaran kerja adalah hukuman yang dijatuhkan pimpinan organisasi kepada karyawan yang melanggar peraturan disiplin yang telah diatur pimpinan organisasi. Menurut Rivai (2015) ada beberapa tingkat dan jenis pelanggaran kerja yang umumnya berlaku dalam organisasi yaitu: 1). Sanksi pelanggaran ringan, dengan jenis: teguran lisan, teguran tertulis, dan penyataan tidak puas secara tertulis. 2). Sanksi pelanggaran sedang, dengan jenis: penundaan kenaikan gaji, penurunan gaji, penundaan kenaikan pangkat. 3). Sanksi pelanggaran berat, dengan jenis: penurunan pangkat, pembebasan dari jabatan, pemberhentian, pemecatan.

Terdapat beberapa indikator yang mempengaruhi tingkat disiplin karyawan dalam suatu perusahaan. Singodimedjo dalam Sutrisno (2016) disiplin dibagi dalam empat dimensi yang diantaranya adalah: 1). Taat terhadap aturan waktu. Dilihat dari jam masuk kerja, jam pulang dan jam istirahat yang tepat waktu sesuai dengan aturan yang berlaku. 2). Taat terhadap peraturan perusahaan. Peraturan dasar tentang cara berpakaian, dan bertingkah laku dalam pekerjaan. 3). Taat terhadap aturan perilaku dalam pekerjaan. Ditunjukkan dengan cara melakukan pekerjaan sesuai dengan jabatan, tugas, dan tanggung jawab serta cara berhubungan dengan unit kerja lain. 4). Taat terhadap norma. Aturan tentang norma-norma apa saja yang berlaku dan yang harus ditaati dan di ikuti oleh para karyawan.

\section{Lingkungan Kerja}

Lingkungan kerja adalah segala sesuatu yang ada disekitar para pekerja yang dapat mempengaruhi dirinya dalam menjalankan tugas-tugas yang diembannya. Menurut Siagian (2014) mengemukakan bahwa "lingkungan kerja adalah lingkungan dimana karyawan melakukan pekerjaan atau tugasnya sehari-hari”. Sedangkan menurut Nitisemito (dalam Nuraini 2014) "lingkungan kerja adalah segala sesuatu yang ada disekitar karyawan dan dapat mempengaruhi dalam menjalankan tugas yang diembankan kepadanya misalnya dengan adanya airconditioner (AC), penerangan yang memadai dan sebagainya". Lain halnya menurut Sedarmayanti (2013) mengemukakan bahwa lingkungan kerja adalah"suatu tempat yang terdapat sebuah kelompok dimana didalamnya terdapat beberapa fasilitas pendukung untuk mencapai tujuan perusahaan sesuai dengan visi dan misi perusahaan".

$$
\text { Menurut Siagian }
$$

menyatakan bahwa secara garis besar, lingkungan kerja terdapat dua jenis yaitu: 1). Lingkungan Kerja Fisik; Lingkungan kerja fisik adalah semua keadaan berbentuk fisik yang terdapat disekitar tempat kerja dan dapat mempengaruhi karyawan. Ada beberapa kondisi fisik dari tempat kerja yang baik yaitu: a). Bangunan tempat kerja disamping menarik untuk dipandang juga dibangun dengan pertimbangan keselamatan kerja. b). Tersedianya peralatan kerja yang memadai. c). Tersedianya tempat istirahat untuk melepas lelah, seperti cafetaria baik dalam lingkungan perusahaan atau sekitarnya yang mudah dicapai karyawan. d). Tersedianya tempat ibadah keagamaan seperti masjid dan musholla untuk karyawan. 
e). Tersedianya sarana angkutan, baik yang diperuntukkan karyawan maupun angkutan umum yang nyaman, murah dan mudah diperoleh. 2). Lingkungan Kerja Non Fisik; Lingkungan kerja non fisik adalah lingkungan kerja yang menyenangkan dalam arti terciptanya hubungan kerja yang harmonis antara karyawan dan atasan, karena pada hakekatnya manusia dalam bekerja tidak hanya mencari uang saja, akan tetapi bekerja merupakan bentuk aktivitas yang bertujuan untuk mendapatkan kepuasan.

Siagian (2014) mengemukakan bahwa lingkungan kerja fisik terdiri dari beberapa indikator yaitu: 1). Bangunan tempat kerja; Bangunan tempat kerja di samping menarik untuk dipandang juga dibangun dengan pertimbangan keselamatan kerja, agar karyawan merasa nyaman dan aman dalam melakukan pekerjaannya. 2). Peralatan kerja yang memadai; Peralatan yang memadai sangat dibutuhkan karyawan karena akan mendukung karyawan dalam menyelesaikan tugas yang di embannya di dalam perusahaan. 3). Fasilitas; Fasilitas perusahaan sangat dibutuhkan oleh karyawan sebagai pendukung dalam menyelasikan pekerjaan yang ada di perusahaan. Selain itu ada hal yang perlu diperhatikan oleh perusahaan yakni tentang cara memanusiakan karyawannya, seperti tersedianya fasilitas untuk karyawan beristirahat setelah lelah bekerja dan juga tersedianya tempat ibadah.

Tersedianya sarana angkutan; Tersedianya sarana angkutan akan mendukung para karyawan untuk sampai di tempat kerja dengan tepat waktu, baik yang diperuntukkan karyawan maupun angkutan umum yang nyaman, murah dan mudah di peroleh.

Lingkungan kerja non fisik adalah terciptanya hubungan kerja yang harmonis antara karyawan dan atasan. Siagian (2014) mengemukakan bahwa lingkungan kerja non fisik terdiri dari beberapa indikator yaitu: 1). Hubungan rekan kerja setingkat; Indikator hubungan dengan rekan kerja yaitu hubungandengan rekan kerja yang harmonis dan tanpa saling intrik di antara sesama rekan sekerja. Salah satu faktor yang dapat mempengaruhi karyawan tetap tinggal dalam satu organisasi adalah adanya hubungan yang harmonis dan kekeluargaan.

2). Hubungan atasan dengan karyawan; Hubungan atasan dengan bawahan atau karyawannya harus di jaga dengan baik dan harus saling menghargai antara atasan dengan bawahan, dengan saling menghargai maka akan menimbulkan rasa hormat diantara individu masing-masing. 3). Kerjasama antar karyawan; Kerjasama antara karyawan harus dijaga dengan baik, karena akan mempengaruhi pekerjaan yang mereka lakukan. Jika kerjasama antara karyawan dapat terjalin dengan baik maka karyawan dapat menyelesaikan pekerjaan mereka secara efektif dan efisien.

\section{Kinerja}

Manajemen sumber daya manusia mempunyai tujuan yaitu untuk meningkatkan kontribusi karyawan terhadap perusahaan dalam rangka mencapai produktivitas perusahaan yang bersangkutan. Keberhasilan sebagai aktivitas perusahaan sangat ditentukan oleh kinerja karyawan yang dimilikinya, semakin baik tingkat kinerja karyawan yang dimiliki oleh perusahaan, semakin baik pula kinerja perusahaan tersebut.

Menurut Mangkunegara (2016) Kinerja merupakan istilah yang berasal dari kata Job Performance atau Actual Performance (prestasi kerja atau kinerja sesungguhnya yang dicapai seseorang). Pengertian kinerja adalah hasil kerja secara kualitas dan kuantitas yang dicapai oleh seorang karyawan dalam melaksanakan tugasnya sesuai dengan tanggung jawab yang diberikan 
kepadanya. Edison (2016) menjelaskan bahwa "kinerja adalah hasil dari suatu proses yang mengacu dan di ukur selama periode waktu tertentu berdasarkan ketentuan atau kesepakatan yang telah ditetapkan sebelumnya". Selanjutnya menurut Robbins dalam Mangkunegara (2014) mengungkapkan : "Kinerja adalah hasil kerja secara kualitas dan kuantitas yang dicapai oleh seorang karyawan dalam melaksanakan tugasnya sesuai dengan tanggung jawab yang di emban kepadanya".

Tujuan evaluasi kinerja adalah untuk memperbaiki atau meningkatkan kinerja organisasi melalui peningkatan kinerja dari sumber daya manusia organisasi. Secara lebih spesifik, tujuan evaluasi kerja sebagaimana dikemukakan Sunyoto dalam Mangkunegara (2014) yaitu: 1). Meningkatkan saling pengertian antara sesama karyawan tentang persyaratan kinerja. 2). Mencatat dan mengakui hasil kerja seorang karyawan, sehingga mereka termotivasi untuk dapat berbuat dengan lebih baik, atau sekurangkurangnya berprestasi yang sama seperti hal nya prestasi yang terdahulu. 3). Memberi peluang kepada karyawan untuk mendiskusikan keinginan dan aspirasinya dalam upaaya meningkatkan kepedulian terhadap karier atau terhadap pekerjaan yang di embannya sekarang. 4). Mendefinisikan atau merumuskan kembali tujuan atau target masa depan, sehingga karyawan termotivasi untuk berpartisipasi sesuai dengan potensinya. 5). Memeriksa rencana pelaksanaan dan pengembangan yang sesuai dengan kebutuhan pelatihan, khususnya dalam rencana pendidikan latihan, dan kemudian menyetujui rencana itu jika tidak ada hal-hal yang perlu diubah.

Sedangkan kegunaan penilaian kinerja karyawan yaitu: 1). Sebagai dasar dalam pengambilan keputusan yang digunakan dalam menilai suatu prestasi, pemberhentian kerja serta besarnya balas jasa. 2). Untuk mengukur sejauh mana seorang karyawan dapat menyelesaikan pekerjaannya.

3). Sebagai dasar dalam mengevaluasi efektivitas seluruh kegiatan dalam perusahaan. 4). Sebagai dasar untuk mengevaluasi program latihan dan ke efektifan jadwal kerja, metode kerja, struktur organisasi, gaya pengawasan, kondisi kerja dan pengawasan. 5). Sebagai indikator untuk menentukan kebutuhan akan latihan bagi karyawan yang berada di dalam organisasi. $\quad 6$ ). Sebagai alat untuk meningkatkan motivasi kerja karyawan sehingga dicapai performance yang baik. 7). Sebagai alat untuk melihat kekurangan atau kelemahan dan meningkatkan kemampuan karyawan selanjutnya. 8). Sebagai kriteria menentukan, seleksi dan penempatan karyawan. 9). Sebagai alat untuk memperbaiki atau mengembangkan kecakapan karyawan. 10). Sebagai dasar untuk memperbaiki atau mengembangkan uraian tugas (job description).

Adapun indikator kinerja menurut Mangkunegara (2014), yaitu: 1). Kualitas kerja; Menunjukan kerapihan, ketelitian, keterkaitan hasil kerja dengan tidak mengabaikan volume pekerjaan. Kualitas kerja yang baik dapat menghindari tingkat kesalahan dalam penyelesaian suatu pekerjaan yang dapat bermanfaat bagi kemajuan organisasi. 2). Kuantitas kerja; Menunjukan banyaknya jumlah jenis pekerjaan yang dilakukan dalam suatu waktu sehingga efisiensi dan efektivitas dapat terlaksana sesuai dengan tujuan organisasi. 3). Tanggung jawab; Menunjukkan seberapa besar karyawan dalam menerima dan melaksanakan pekerjaannya, mempertanggungjawabkan hasil kerja, serta dan prasarana yang digunakan. 4). Kerjasama; Kesediaan karyawan untuk berpartisipasi dengan karyawan yang lain secara vertikal dan horizontal baik didalam maupun diluar pekerjaan sehingga hasil pekerjaan akan 
semakin baik. 5). Inisiatif; Inisiatif dari dalam diri anggota melakukan pekerjaan serta mengatasi masalah dalam pekerjaan tanpa menunggu perintah dari atasan atau menunjukan tanggung jawab dalam pekerjaan yang sudah kewajiban seorang karyawan.

\section{METODE PENELITIAN}

Penelitian ini merupakan penelitian asosiatif kausal dengan pendekatan kuantitatif. Populasi penelitian ini adalah sebanyak 232 karyawan PT. Sarana Reswara Abadi dan Sampel penelitian berjumlah 70 karyawan yang diambil berdasarkan rumus slovin dengan teknik pengambilan sampel secara acak. Pengumpulan data menggunakan kuesioner yang telah diuji validitas dan reliabilitasnya. Teknik analisis data dilakukan dengan menggunakan analisis regresi linear sederhana maupun berganda.

\section{HASIL PENELITIAN DAN PEMBAHASAN}

\section{Hasil Penelitian}

\section{Uji instrumen data}

Berdasarkan uraian tersebut untuk dapat menentukan apakah variabel disiplin dan lingkungan kerja dapat dijadikan pengukur terhadap kinerja karyawan PT. Sarana Reswara Abadi. Namun sebelumnya data diolah terlebih dahulu dan dilakukan pengujian terhadap varibel yang digunakan yaitu disiplin dan lingkungan kerja untuk mengetahui apakah data tersebut akurat dan dapat dipercaya.

\section{Uji validitas}

Pengujian validitas ini dilakukan untuk menguji apakah tiap butir pernyataan telah mewakili indikator yang akan diteliti, persyaratan minimum untuk dapat dikatakan valid adalah $\mathrm{r}=0,30$. Jadi, apabila korelasi antara butir-butir item pernyataan dengan skor total kurang dari 0,30, maka butiran dalam instrumen tersebut dapat dikatakan tidak valid. Uji validitas dilakukan dengan melihat korelasi antara skor masing-masing item pernyataan dengan skor total. (Sugiyono, 2017).

Dari perhitungan koefisien korelasi skor tiap butir pernyataan dari 70 responden tentang instrument disiplin, dengan jumlah 10 pernyataan; instrumen lingkungan kerja 10 pernyataan dan instrumen kinerja karyawan 10 pernyataan dengan total skor setiap responden diperoleh hasil $r$ hitung lebih besar dari $\mathrm{r}$ kritis 0,300 .

\section{Uji reliabilitas}

Pengujian reliabilitas ini dilakukan untuk menguji seberapa jauh hasil pengukuran yang dapat diandalkan secara konsisten. Pada tabel hasil pengujian reliabilitas berikut, diketahui bahwa semua variabel mempunyai alpha di atas 0,6 yang berarti bahwa semua variabel dalam penelitian ini dapat diandalkan.

Tabel 2: Hasil Uji Reliabilitas Variabel

\begin{tabular}{lcc}
\hline \multicolumn{1}{c}{ Variabel } & Cronbach's Alpha & Keterangan \\
\hline Disiplin & 0.834 & Reliabel \\
Lingkungan Kerja & 0.608 & Reliabel \\
Kinerja Karyawan & 0.842 & Reliabel \\
\hline
\end{tabular}

Sumber: Hasil pengolahan data, 2020 
Berdasarkan Tabel 2, dapat disimpulkan bahwa nilai Cronbach's Alpha positif dimana lebih besar dari 0,6 yang merupakan batas minimal koefisien reliabilitas dapat dianggap baik dan reliabel.

\section{Analisis regresi sederhana}

Tabel 3: Pengaruh Disiplin terhadap Kinerja Karyawan

\begin{tabular}{lccccc}
\hline \multirow{2}{*}{ Variabel } & $\begin{array}{c}\mathbf{R} \\
\text { Square }\end{array}$ & Konstanta & $\begin{array}{c}\text { Koefisien } \\
\text { Regresi }\end{array}$ & Sig. & $\boldsymbol{\alpha}$ \\
\hline Disiplin & 0.656 & 8.522 & 0.833 & 0.000 & 0.01 \\
\hline Pengujian Signifikansi & & & & & \\
\hline t hitung $>$ t tabel $=11.378>1.995$ & & & & \\
\hline
\end{tabular}

\section{Keterangan : Variabel Kinerja Karyawan}

Sumber: data diolah 2020

Tabel 3, nilai koefisien determinasi $\left(\mathrm{R}^{2}\right)$ sebesar 0.656, artinya disiplin memberikan kontribusi sebesar 65,6\% kepada kinerja karyawan PT. Sarana Reswara Abadi, sedangkan sisanya sebesar 34,4\% disumbangkan faktor lain yang tidak diteliti, seperti lingkungan kerja.
Disiplin berpengaruh positif dan signifikan pada tingkat nyata 99\% terhadap kinerja karyawan PT. Sarana Reswara Abadi. Koefisien disiplin bertanda positif, artinya jika ada peningkatan disiplin, maka kinerja karyawan PT. Sarana Reswara Abadi akan meningkat atau sebaliknya.

Persamaan Regresi $\mathrm{Y}=8,522+0,833\left(\mathrm{X}_{1}\right)$

Tabel 4: Pengaruh Lingkungan Kerja terhadap Kinerja Karyawan

\begin{tabular}{lccccc}
\hline \multirow{2}{*}{ Variabel } & \multicolumn{6}{c}{ Parameter } \\
\cline { 2 - 6 } & \multicolumn{1}{c}{$\begin{array}{c}\text { Rquare } \\
\text { Ling_Kerja }\end{array}$} & Konstanta & $\begin{array}{c}\text { Koefisien } \\
\text { Regresi }\end{array}$ & Sig & $\boldsymbol{\alpha}$ \\
\hline Pengujian Signifikan & 0,558 & 8,691 & 0,883 & 0,000 & 0.01 \\
\hline t hitung > t tabel = 9,272 $>1,995$ & & & & \\
\hline $\begin{array}{l}\text { Keterangan: Variabel Kinerja Karyawan } \\
\text { Sumber : data diolah 2020 }\end{array}$
\end{tabular}

Pada Tabel 4, nilai koefisien determinasi $\left(\mathrm{R}^{2}\right)$ sebesar 0.558 , artinya lingkungan kerja memberikan kontribusi sebesar 55,8\% kepada kinerja karyawan PT. Sarana Reswara Abadi, sedangkan sisanya sebesar $44,2 \%$ disumbangkan faktor lain yang tidak diteliti, seperti disiplin.

Persamaan Regresi $\mathrm{Y}=8,691+0,883\left(\mathrm{X}_{2}\right)$
Lingkungan kerja berpengaruh positif dan signifikan pada tingkat nyata 99\% terhadap kinerja karyawan PT. Sarana Reswara Abadi. Koefisien lingkungan kerja bertanda positif, artinya jika ada perbaikan lingkungan kerja, maka kinerja karyawan PT. Sarana Reswara Abadi akan meningkat atau sebaliknya. 
Tabel 5: Pengaruh Disiplin dan Lingkungan Kerja terhadap Kinerja Karyawan

\begin{tabular}{|c|c|c|c|c|c|}
\hline \multirow[b]{2}{*}{ Variabel } & \multicolumn{4}{|c|}{ Parameter } & \multirow[b]{2}{*}{$\alpha$} \\
\hline & $\begin{array}{c}\mathbf{R} \\
\text { Square }\end{array}$ & Konstanta & $\begin{array}{c}\text { Koefisien } \\
\text { Regresi }\end{array}$ & Sig. & \\
\hline $\begin{array}{l}\text { Disiplin } \\
\text { Ling_Kerja }\end{array}$ & 0,715 & 2,761 & $\begin{array}{l}0,580 \\
0,409\end{array}$ & $\begin{array}{l}0,000 \\
0,000\end{array}$ & 0.01 \\
\hline
\end{tabular}

Pengujian Signifikan

F hitung $>\mathrm{F}$ tabel $=84,045>3,134$

Keterangan: Variabel Kinerja Karyawan

Sumber: data diolah 2020

Berdasarkan Tabel 5, nilai $\mathrm{F}$ hitung lebih besar dari $\mathrm{F}$ tabel $(84,045>3,134)$, maka Ho tolak, Ha terima, artinya secara bersama-sama ada pengaruh yang positif dan signifikan disiplin dan lingkungan kerja terhadap kinerja karyawan PT. Sarana Reswara Abadi. Nilai koefisien determinasi $\left(\mathrm{R}^{2}\right)$ sebesar 0.715 , artinya disiplin dan lingkungan kerja secara bersama-sama memberikan kontribusi sebesar $71,5 \%$ kepada kinerja karyawan PT. Sarana Reswara Abadi, sedangkan sisanya sebesar $28,5 \%$ disumbangkan faktor lain yang tidak dibahas dalam penelitian ini.

Persamaan Regresi $\mathrm{Y}=2,761+0,580\left(\mathrm{X}_{1}\right)$ $+0,409\left(\mathrm{X}_{2}\right)$

Disiplin dan lingkungan kerja secara bersama-sama berpengaruh positif dan signifikan terhadap kinerja karyawan PT. Sarana Reswara Abadi pada tingkat nyata 99\%. Koefisien disiplin bertanda positif, artinya jika ada peningkatan disiplin, maka kinerja karyawan PT. Sarana Reswara Abadi akan meningkat atau sebaliknya dengan asumsi lingkungan kerja tidak berubah. Koefisien lingkungan kerja bertanda positif, artinya jika ada perbaikan lingkungan kerja, maka kinerja karyawan PT. Sarana Reswara Abadi akan meningkat atau sebaliknya, dengan asumsi disiplin tidak berubah.

\section{Pembahasan}

Pengaruh Disiplin Terhadap Kinerja Karyawan PT. Sarana Reswara Abadi

Hasil penelitian ini menunjukkan bahwa disiplin yang dilaksanakan dengan baik akan mendorong peningkatan kinerja karyawan. Hal ini dikarenakan bahwa karyawan datang dan pulang tepat waktu, dalam istirahat juga tepat waktu, bekerja sesuai dengan waktu yang ditentukan, karyawan bekerja mengenakan seragam kerja sesuai yang ditentukan, mengenakan tanda pengenal di perusahaan, bekerja sesuai tugas yang diberikan, mengerjakan pekerjaan dengan baik sesuai prosedur, bertindak sopan santun di lingkungan kerja, apabila tidak mematuhi aturan maka tidak menunjukkan sikap disiplin dan setiap karyawan bersedia mematuhi dan menjalankan aturan yang telah ditetapkan perusahaan. Hasil penelitian ini sesuai dengan penelitian yang dilakukan oleh Fitriana (2012), dan Mukeri (2015), yaitu menganalisis pengaruh disiplin terhadap kinerja karyawan. Dengan demikian hipotesis pertama diterima.

\section{Pengaruh Lingkungan Kerja Terhadap Kinerja Karyawan PT. Sarana Reswara Abadi}

Hasil penelitian ini menunjukkan bahwa lingkungan kerja yang nyaman dapat mendorong peningkatan kinerja karyawan. Hal ini dikarenakan bahwa penerangan di area kerja sesuai kebutuhan, kondisi udara memberikan 
kenyamanan dalam bekerja, lingkungan kerja agak bising namun APD dapat mengurangi efeknya, bahan kimia yang digunakan sesuai prosedur sehingga tidak membahayakan, kelembaban udara tidak menggangu suhu tubuh dalam bekerja, fasilitas kerja memadai dalam berkativitas, alat pelindung diri sesuai dengan kebutuhan karyawan, hubungan sesama rekan kerja harmonis, setiap karyawan memiliki kesempatan dalam promosi kerja, dan tempat kerja menjamin karyawannya dengan aman. Hasil penelitian ini sejalan dengan penelitian yang dilakukan oleh Bachtiar (2012), dan Putra, et al, (2013), yaitu menganalisis pengaruh lingkungan kerja terhadap kinerja karyawan. Dengan demikian hipotesis kedua diterima.

\section{Pengaruh Disiplin dan Lingkungan Kerja Terhadap Kinerja Karyawan PT. Sarana Reswara Abadi}

Berdasarkan hasil analisis diketahui bahwa disiplin dan lingkungan kerja dapat mendorong peningkatan kinerja karyawan PT. Sarana Reswara Abadi. Hasil penelitian ini sama dengan hasil penelitian yang dilakukan oleh Liawandy, et al, (2014), Ferawati (2017), Lusiana (2018), yaitu menganalisis pengaruh disiplin dan lingkungan kerja terhadap kinerja karyawan. Dengan demikian hipotesis ketiga diterima.

\section{KESIMPULAN DAN SARAN}

\section{Kesimpulan}

Berdasarkan hasil penelitian dan pembahasan, maka dapat ditarik beberapa kesimpulan sebagai berikut: 1). Disiplin berpengaruh positif dan signifikan terhadap kinerja karyawan PT. Sarana Reswara Abadi. 2). Lingkungan kerja berpengaruh positif dan signifikan terhadap kinerja karyawan PT. Sarana Reswara Abadi. 3). Secara bersama-sama disiplin dan lingkungan kerja berpengaruh signifikan terhadap kinerja karyawan PT. Sarana Reswara Abadi.

\section{Saran}

Berdasarkan hasil penelitian, pembahasan, dan kesimpulan yang diperoleh, maka saran yang dapat diberikan sebagai berikut: 1). Bagi Pimpinan PT. Sarana Reswara Abadi; a). Berdasarkan hasil penilaian karyawan PT. Sarana Reswara Abadi diketahui bahwa variabel disiplin karyawan masih terlihat kurang yang oleh karena itu, pimpinan PT. Sarana Reswara Abadi disarankan untuk lebih tegas dalam menghadapi sikap karyawan yang dinilai kurang memperhatikan waktu istirahat dalam bekerja. Pimpinan disarankan juga untuk lebih ketat dan tegas dalam mengawasi karyawan terhadap tugas yang sudah diberikan padanya, kiranya peraturan tentang karyawan dapat dipatuhi. Pemberian sanksi yang tepat juga perlu dipertimbangkan guna mendapatkan hasil yang diinginkan demi kebaikan perusahaan. b). Berdasarkan hasil penilaian karyawan PT. Sarana Reswara Abadi diketahui bahwa variabel lingkungan kerja masih banyak yang perlu ditingkatkan, oleh karena itu, pimpinan PT. Sarana Reswara Abadi disarankan untuk selalu mengontrol dan menjaga lingkungan kerja yang berada di area dimana karyawan melakukan aktivitas pekerjaan dan juga perlengkapan APD yang diberikan harus dapat memenuhi standar nasional yang sudah diakui pemerintah. 2). Bagi Peneliti Selanjutnya; Bagi peneliti yang tertarik melakukan penelitian sejenis diharapkan untuk mengobservasi dan mengembangkan lebih jauh mengenai permasalahanyang terdapat pada PT. Sarana Reswara Abadi khususnya dan objek lain pada umumnya dengan menambahkan variabel lain yang berhubungan dengan kinerja karyawan. 


\section{DAFTAR PUSTAKA}

Bachtiar. 2012. "Pengaruh Motivasi dan Lingkungan Kerja terhadap Kinerja Karyawan study pada PT. Aqua Tirta Investama di Klaten". Management Analysis Journal, Vol.1, No.1.

Dharma, Surya. 2012. Manajemen Kinerja Falsafah Teori dan Penerapannya. Yogyakarta: Pustaka Pelajar

Davis, Keith E. 1985. Human Behavior at Work: Organization Behavior. New York: McGraw-Hill.

Edison. 2016. Manajemen Sumber Daya Manusia, Bandung: Alfabeta.

Ferawati, Apfia. 2017. "Pengaruh Lingkungan Kerja dan Disiplin Kerja Terhadap Kinerja Karyawan". Journal Article None Vol. 5, No. 1, 2017.

Fitriana, Nina. 2012. "Pengaruh Disiplin Kerja dan Pengawasan Terhadap Kinerja Karyawan PT. Pelabuhan Indonesia II (PERSERO) Cabang Palembang”. Jurnal Kompetitif Vol. 1, No. 1, 2012.

Liawandy, Feru., Indarti, Sri dan Marzolina. 2014. "Pengaruh Disiplin dan Lingkungan Kerja terhadap Kinerja Karyawan bagian produksi PT. Nafal Tiara Abadi Pekanbaru". JOM FEKON, Vol. 1, No.2, 2014.

Lusiana, Herlina. 2018. "Pengaruh Disiplin dan Lingkungan Kerja Terhadap Kinerja Karyawan PT. Tanjung Selatan Makmur Jaya Kalimantan Selatan". Jurnal AlUlum Ilmu Sosial dan Humaniora. Vol. 4 No. 1, 2018.

Mangkunegara, Anwar Prabu. 2017. Manajemen Sumber Daya Manusia Perusahaan, Cetakan Kesepuluh, Bandung: PT. Remaja Rosdakarya Offset.
Mukeri. 2015. "Effect of Supervision and Discipline on the Perfomance of Employees Working SATUAN POLISI PAMONG PRAJAKOTA SEMARANG". Journal of Management : ISSN Vol 1, No 1, 2015.

Nitisemito, Alex S., 2014. Manajemen Personalia dan Manajemen Sumber Daya Manusia. Edisi Ketiga. Jakarta: Ghalia Indonesia.

Putra, Fariz Ramanda., Utami, Hamidah Nayati, dan Hakam, Muhammad Soe'oed. 2013. "Pengaruh Lingkungan Kerja terhadap Kinerja studi pada karyawan PT. Naraya Telematika" Malang. Jurnal Administrasi Bisnis, Vol.6, No.1.

Rivai, Veithzal, 2015. Manajemen Sumber Daya Manusia untuk Perusahaan : dari Teori Ke Praktik, Edisi Pertama, Jakarta: Penerbit PT. Raja Grafindo Persada.

Robbins, Stephen P. 2007. Perilaku Organisasi. Jakarta: PT Indeks

Sedarmayanti. 2013. Manajemen Sumber Daya Manusia. Bandung: PT. Refika Aditama.

Setiawan, Agung. 2013. "Pengaruh Disiplin Kerja dan Motivasi Terhadap Kinerja Karyawan Pada Rumah Sakit Umum Daerah Kanjuruan Malang”. Jurnal Ilmu Manajemen. Vol 1, No 4; Juli 2013. Siagian, Sondang P. 2014. Manajemen Sumber Daya Manusia. Jakarta: Bumi Aksara.

Sidanty. Heny. 2015. Pengaruh Lingkungan Kerja, Disiplin Kerja dan Motivasi Kerja Terhadap Kinerja Pegawai Negeri Sipil Di Sekretariat DPRD Kabupaten Madiun, Jurnal JIBEKA, Vol 9, No 1. http://lp3m.asia.ac.id.

Singodimedjo, Markum. 2000. Menejemen Sumber Daya Manusia. Surabaya: SMMAS.

Sugiyono. 2017. Statikstika Untuk Penelitian. Bandung: Alfabeta. 
Sunyoto, Danang. 2013. Manajemen Sumber Daya Manusia. Jakarta: Center for Academic Publishing Service
Sutrisno, Edy 2016, Manajemen Sumber Daya Manusia, Cetakan Kedelapan, Jakarta: Prenamedia Group. 